\title{
EVALUASI TINGKAT KELAYAKAN KUALITAS AIR DAN PENCEMARAN PADA TAMBAK POLIKULTUR BERDASARKAN KEPADATAN PLANKTON DI DESA PELANGWOT KECAMATAN LAREN KABUPATEN LAMONGAN
}

\author{
Agung Pamuji Rahayu, Muntalim* \\ *Fakultas Perikanan, Universitas Islam Lamongan \\ Jl. Veteran no. 53A Lamongan Phone/Fax.0322_324706
}

\begin{abstract}
ABSTRAK
Kegiatan budidaya ikan Bandeng (Chanos chanos) dan Udang Vannamei (Lithopenaeus vannamei) sistem polikultur di wilayah Kabupaten Lamongan, Propinsi Jawa Timur khususnya daerah tambak sudah lama diterapkan oleh pembudidaya ikan sebagai upaya untuk meningkatkan hasil produksi perikanan budidaya sekaligus meningkatkan pendapatan masyarakat. Kegiatan budidaya sistem polikultur juga tidak luput dari permasalahan mulai dari menurunnya kualitas air hingga kematian ikan. Kualitas air merupakan salah satu faktor yang menjadi keberhasilan usaha budidaya ikan. Data dan informasi mengenai kondisi kualitas air dan tingkat pencemaran di tambak dapat diketahui dengan melakukan evaluasi kualitas air dan perhitungan indeks saprobik berdasarkan kepadatan dan komunitas plankton sehingga dapat diketahui tingkat kesesuaian kualitas air dan pencemaran air ditambak pada kondisi sekarang. Tujuan penelitian adalah mengetahui tingkat kesesuaian kualitas air dan pencemaran berdasarkan kepadatan dan komunitas plankton. Jenis penelitian adalah kuantitatif dengan metode yang digunakan adalah metode deskriptif. Berdasarkan nilai kelimpahan pada stasiun 1, 2, dan 3 maka perairan di tambak polikultur pada kategori eutropik, karena > $15.000 \mathrm{Ind} / \mathrm{L}$. Nilai indeks keanekaragaman berada pada kisaran 0.125-0,049 artinya menunjukkan keanekaragaman kecil dan kestabilan rendah. Sedangkan rata-rata nilai indek dominansi berkisar 0,013-0,019, mendekati angka 0, sehingga dapat disimpulkan tidak ada plankton yang mendominasi perairan. Pada pengukuran parameter kualitas air di semua stasiun, suhu berada pada kisaran 28,6-29,7 0C, DO berada pada nilai kisaran 4,1-5,6 mg/L, $\mathrm{pH}$ berkisar 8,4-9,5 dalam kondisi tinggi, sehingga dapat mengakibatkan pertumbuhan terganggu. Salinitas berkisar 1,9-5,0 aman untuk perairan tawar dan kecerahan cenderung pekat berkisar 17,5-20 cm. Nilai indeks saprobik di tambak polikultur menunjukkan bahwa perairan tersebut tergolong tercemar sangat ringan berada di Stasiun II dengan nilai 1,63 hingga agak tinggi ( $\alpha$ - Mesosaprobik) pada Stasiun III, yaitu 0,73 .
\end{abstract}

Kata Kunci : Polikultur, plankton, kualitas air

\section{PENDAHULUAN}

Kabupaten Lamongan memiliki luas wilayah kurang lebih $1.812,80 \mathrm{Km}^{2}$ setara $181.280 \mathrm{Ha}$ atau $\pm 3.78 \%$ dari luas wilayah Propinsi Jawa Timur dengan panjang garis pantai sepanjang $47 \mathrm{Km}$. Kabupaten Lamongan merupakan salah satu wilayah yang sangat strategis termasuk sentra produksi perikanan budidaya dan tangkap di Provinsi Jawa Timur Luas lahan budidaya ikan di Kabupaten Lamongan pada tahun 2011 sebesar 25.313 Ha. Khusus untuk pengembangan perikanan tambak (perairan air payau) dengan luas kurang lebih 1.745,4 ha (DPK, 2014). Kawasan sawah tambak 
merupakan sistem budidaya polikultur ikan Bandeng (Chanos chanos) dan Udang Vannamei (Lithoipenaeus vannamei) pada perairan tawar yang tersebar di wilayah utara dan selatan Sungai Bengawan Solo yang melintasi Kabupaten Lamongan. Masyarakat di Desa Pelangwot Kecamatan Laren Kabupaten Lamongan memulai usaha budidaya ikan polikultur mulai tahun 2005 . Menurut Syahid et al., (2006) bahwa Polikultur adalah sutu metode budidaya yang digunakan untuk memelihara organisme/kultivan lebih dari satu produk dalam satu lahan. Sehingga dengan sistem ini dapat dirasakan manfaatnya yaitu dengan semakin meningkatnya produktivitas lahan yang digunakan karena dapat memanen lebih dari satu komoditas ikan dalam satu musim sehingga secara otomatis dapat menambah penghasilan mereka. Pada kegiatan budidaya masih banyak kendala yang ditemui oleh para pembudidaya ikan antara lain menurunnya kualitas air dan tingkat pencemaran perairan tambak sehingga dapat menimbulkan kematian ikan. Menurut Raymont (1980) dalam Fachrul (2005) perubahan terhadap kualitas perairan erat kaitannya dengan potensi perairan ditinjau dari kelimpahan dan komposisi plankton, sedangkan menurut Guo (1991) dalam Fachrul (2005) bahwa keberadaan plankton pada perairan dapat memberikan informasi mengenai kondisi perairan, sehingga plankton merupakan parameter biologi yang dapat dijadikan indikator untuk mengevaluasi kualitas dan kesuburan perairan. Kesuburan suatu perairan antara lain dapat dilihat dari keberadaan organisme planktonnya, karena plankton dalam suatu perairan dapat menggambarkan tingkat produktivitas perairan tersebut (Sachlan, 1980). Menurut (Sagala, 2010) terganggunya kehidupan baik kelimpahan dan komposisinya akan sangat mengganggu untuk organisme perairan lainnya yaitu keanekaragaman dan produksi ikan disekitarnya. Mengingat pentingnya peranan plankton sebagai jasad alami dan produsen ekosistem akuatik, maka perlu dilakukan penelitian mengenai komposisi dan kelimpahan plankton untuk mengetahui kelayakan kualitas air dan indeks saprobik yang akan menggambarkan besarnya beban pencemaran yang terjadi pada perairan tambak.

\section{BAHAN DAN METODE}

Penelitian dilakukan bulan 27 September 2016 sampai dengan 27 Oktober 2017 di Dusun Lengor, Desa Pelangwot, Kecamatan Laren Kabupaten Lamongan. Jenis penelitian yaitu penelitian kuantitatif dan metode penelitian yang digunakan adalah metode deskriptif. Lokasi atau stasiun pengambilan contoh ditentukan secara purposive pada 3 stasiun pengamatan yaitu 1). Stasiun I Tambak berada dekat pemukiman penduduk, 2) Stasiun II Tambak berada dekat dengan sumber air (Sungai Bengawan Solo), 3) Stasiun III Tambak berada jauh dari pemukiman dan sumber air. Pengumpulan data dilakukan secara observasi lapangan untuk melakukan pengukuran kualitas air dan pengambilan sampel plankton disetiap stasiun. Identifikasi sample plankton dilaksanakan di Laboratorium Manajemen Sumberdaya Perairan Fakultas Perikanan Universitas Islam Lamongan.

Alat yang digunakan dalam penelitian Evaluasi Tingkat Kelayakan Kualitas Air dan Pecemaran Pada Tambak Polikultur Berdasarkan Kepadatan Plankton di Desa Plangwot, Kecamatan Laren, Kabupaten Lamongan meliputi alat pengukur parameter kualitas air yaitu DO Meter, pH meter, Refraktometer, Secchi Disk dan Termometer $\mathrm{Hg}$, sedangkan untuk pengambilan sampel 
plankton dan identifikasi plankton menggunakan planktonet dengan ukuran mata jaring $25 \mu \mathrm{m}$, gayung ukuran 1,3 liter, botol film $100 \mathrm{~mm}$, Mikroskop Trinokumer, SRC (Sedgewick Rafter Count), pipet tetes dan buku identifikasi plankton (Freshwater Algae). Bahan yang digunakan yaitu Larutan Lugol 4.

Penelitian ini dilakukan melalui tahapan yang sistematis, logis dan terstruktur, yang terdiri dari 2 tahapan, yaitu :

\section{Analisis kelimpahan, Keanekaragaman, Dominasi plankton dan Uji T}

Analisis kelimpahan plankton mengacu kepada Wardhana (2003) dalam Suyoto (2013), pencacahan plankton dilakukan dengan menghitung jumlah plankton per satuan volume, Kepadatan plankton dalam sel atau individu per satuan volume dapat diketahui dengan mempergunakan rumus sebagai berikut :

$$
\mathbf{D}=\mathbf{q}\left(\frac{\mathbf{1}}{\mathbf{f}}\right)\left(\frac{\mathbf{1}}{\mathbf{V}}\right)
$$

Dimana :

D : Jumlah plankter per satuan volume ( Ind/l

Q : Jumlah plankter dalam subsampel ( Ind )

F : fraksi yang diambil (volume subsampel per volume meks Dominansi dihitung dengan sampel )

$\mathrm{V}:$ Volume air yang tersaring $(\mathrm{ml})=250 \mathrm{~m}$

Volume sampel di dalam botol film dinyatakan dalam simbol "I " dan untuk mengetahui volume sampel air, terlebih dahulu dihitung volume botol film dengan mempergunakan rumus :

$$
\mathbf{v}=\pi r^{2} \mathbf{t}(\text { di konversi dalam liter ) }
$$

Volume subsampel dinyatakan dalam simbol "p" dengan volume $0,1 \mathrm{ml}$, sedangkan volume air yang tersaring diketahui $250 \mathrm{ml}$.
Kelimpahan organisme dalam perairan dapat dinyatakan sebagai jumlah individu per liter. Murdjani dan Darmawan (2005) menggolongkan perairan berdasarkan kelimpahan individu yaitu suatu perairan dengan kelimpahan $<10.000 \mathrm{Ind} / \mathrm{L}$ adalah termasuk dalam perairan dengam tingkat kelimpahan rendah (Oligotrooph), kelimpahan antara $10.000-12.000 \mathrm{Ind} / \mathrm{L}$ termasuk dalam tingkat sedang (Mesotrooph), dan perairan dengan kelimpahan >12.000 Ind/L adalah tingkat tinggi (Eutrooph).

Untuk menghitung keanekaragaman, maka digunakan indeks keanekaragaman ShannonWiener (Romimohtarto dan Juwana, 2005) sebagai petunjuk pengolahan data :

$$
\mathbf{H}^{\prime}=-\Sigma(\mathbf{n i} / \mathbf{N}) \ln (\mathbf{n i} / \mathbf{N})
$$

Dimana :

$\mathrm{H}^{\prime}=$ Indeks Diversitas Shannon-Wienner

$\mathrm{Ni}=$ Jumlah individu/spesies

$\mathrm{N}=$ Jumlah individu keseluruhan

Indeks keseragaman adalah perbandingan keanekaragaman maksimal dalam suatu komunitas. Nilai indeks keseragaman antara 0 - 1, makin besar nilainya berarti penyebaran individu tiap jenis atau genera semakin merata dan tidak ada spesies yang mendominasi, begitu pula sebaliknya.

menggunakan rumus indeks dominanasi dari Simpson (Odum, 1971 dalam Suyoto, 2013)

Dimana :

$$
\text { D }=\Sigma(\mathrm{ni} / \mathrm{N})^{2}
$$

$$
\begin{aligned}
& \mathrm{D}=\text { Indeks Dominansi Simpson } \\
& \mathrm{ni}=\text { Jumlah Individu tiap spesies } \\
& \mathrm{N}=\text { Jumlah Individu seluruh spesies }
\end{aligned}
$$

Indeks dominansi berkisar antara 0 sampai 1, dimana semakin kecil nilai indeks dominansi maka menunjukan bahwa tidak ada spesies yang mendominsi sebaliknya semakin besar 
dominansi maka menunjukan ada spesies tertentu (Odum, 1971 dalam Yazwar, 2008).

Uji $\mathrm{T}$ digunakan untuk mengetahui hubungan parameter fisika-kimia terhadap parameter biologi. Adapun rumus dari uji $\mathrm{T}$ yang di pergunakan untuk mengetahui adanya perbedaan yang signifikan dari keanekaragaman plankton antar stasiun adalah sebagai berikut (Zar, 1999 dalam Yazwar, 2008) :

$$
\mathrm{t}=\mathrm{H}^{\prime}{ }_{1}-\mathrm{H}^{\prime}{ }_{2} / \mathrm{S}_{\mathrm{H}^{\prime} \mathbf{1}^{-}}-\mathrm{S}_{\mathrm{H}^{\prime} \mathbf{2}}
$$

dimana :

t : Nilai t hitung yang di cari

$\mathrm{H}^{\prime}$ : Indeks keanekaragaman

SH': Standard Deviasi Keanekaragaman

\section{Analisis Indeks Saprobik komunitas plankton untuk tingkat pencemaran perairan}

Tabel 1. Nilai Indeks Saprobik dengan Penafsiran Kualitas Air Secara Biologis

\begin{tabular}{|c|c|c|c|c|}
\hline $\begin{array}{l}\text { Beban } \\
\text { Pencemar } \\
\text { an }\end{array}$ & $\begin{array}{l}\text { Derajat } \\
\text { Pencema } \\
\text { ran }\end{array}$ & $\begin{array}{l}\text { Fase } \\
\text { Saprobik }\end{array}$ & $\begin{array}{l}\text { Indeks } \\
\text { Saprobik }\end{array}$ & $\begin{array}{l}\mathrm{C}: \text { Group Chloroccales + Diatomae, } \\
\text { menunjukkan } \beta \text { Mesosaprobitas }\end{array}$ \\
\hline $\begin{array}{l}\text { Banyak } \\
\text { Senyawa } \\
\text { Organik } \\
\end{array}$ & $\begin{array}{l}\text { Sangat } \\
\text { Tinggi }\end{array}$ & $\begin{array}{l}\text { Polisaprobik } \\
\text { Poli/ } \alpha- \\
\text { Mesosaprobik }\end{array}$ & $\begin{array}{l}-3 \mathrm{~s} / \mathrm{d}-2 \\
-2 \mathrm{~s} / \mathrm{d}-1,5\end{array}$ & $\begin{array}{l}\text { Peridinae/Chrysophyceae/Conjugatae, } \\
\text { Oligosaprobitas }\end{array}$ \\
\hline $\begin{array}{l}\text { Senyawa } \\
\text { Organik } \\
\text { dan }\end{array}$ & $\begin{array}{l}\text { Agak } \\
\text { Tinggi }\end{array}$ & $\begin{array}{l}\alpha- \\
\text { Meso/polisapr } \\
\text { obik }\end{array}$ & $\begin{array}{l}1,5 \mathrm{~s} / \mathrm{d}-1 \\
-1 \mathrm{~s} / \mathrm{d}-0,5\end{array}$ & HASIL DAN PEMBAHASAN \\
\hline Anorganik & & $\begin{array}{l}\alpha- \\
\text { Mesosaprobik }\end{array}$ & & HASIL \\
\hline $\begin{array}{l}\text { Sedikit } \\
\text { senyawa }\end{array}$ & Sedang & $\begin{array}{l}\alpha / \beta- \\
\text { Mesosaprobik }\end{array}$ & & $\begin{array}{l}\text { Kelimpahan Plankton } \\
\text { Dalam penelitian jumlah plankton }\end{array}$ \\
\hline $\begin{array}{l}\text { organik } \\
\text { dan } \\
\text { anorganik }\end{array}$ & & $\begin{array}{l}\beta / \alpha \\
\text { Mesosaprobik }\end{array}$ & $0 \mathrm{~s} / \mathrm{d}+0,5$ & $\begin{array}{l}\text { di Stasiun } 1 \text { didapatkan sejumlah } 16 \\
\text { genera dengan kelimpahan rata-rata sebesar }\end{array}$ \\
\hline & $\begin{array}{l}\text { Ringan/ } \\
\text { sedang }\end{array}$ & $\begin{array}{l}\beta- \\
\text { Mesosaprobik }\end{array}$ & $+0,5 \mathrm{~s} / \mathrm{d}+1$ & $\begin{array}{l}-52.060 \text { individu/L. Dalam hal jenis } \\
\text { kelimpahan plankton yang tertinggi }\end{array}$ \\
\hline & & $\begin{array}{l}\beta- \\
\text { Meso/Oligosa } \\
\text { probik }\end{array}$ & $+1 \mathrm{~s} / \mathrm{d}+1,5$ & $\begin{array}{l}\text { yaitu Batrachospermum dengan kelimpahan } \\
\text { rata-rata } 622.427 \text { individu/L. Sementara } \\
\text { ienis plankton vang mempunvai kelimpahan }\end{array}$ \\
\hline & $\begin{array}{l}\text { Sangat } \\
\text { ringan }\end{array}$ & $\begin{array}{l}\text { Oligo/ß- } \\
\text { Mesosaprobik } \\
\text { Oligosaprobik }\end{array}$ & $\begin{array}{l}+1,5 \mathrm{~s} / \mathrm{d}+2 \\
+2 \mathrm{~s} / \mathrm{d}+3\end{array}$ & $\begin{array}{l}\text { terendah yaitu Stephanodiscus dan Ulothrix } \\
\text { dengan kelimpahan } 471 \text { individu/L. Jumlah }\end{array}$ \\
\hline
\end{tabular}


didapatkan sejumlah 17 genera dengan kelimpahan rata-rata sebesar 17.926 individu/L. Dalam hal jenis kelimpahan plankton yang tertinggi yaitu Gyrosigma frustulemarkings dengan kelimpahan ratarata 124.344 individu/L. Sementara jenis plankton yang mempunyai kelimpahan terendah yaitu Lemanea, Myxophyta, Nostoc, Tabellaria floculosa dengan kelimpahan 942 individu/ml. Stasiun 3 mempunyai kelimpahan plankton rata-rata sebesar 81.302 individu/L yang terdiri dari 13 genera. Jenis plankton yang mempunyai kelimpahan tertinggi yaitu Coelosphaerium dengan kelimpahan rata-rata 493.137 individu/L. Sementara jenis plankton yang mempunyai kelimpahan terendah yaitu Monorophidium dengan kelimpahan 942 individu/L.

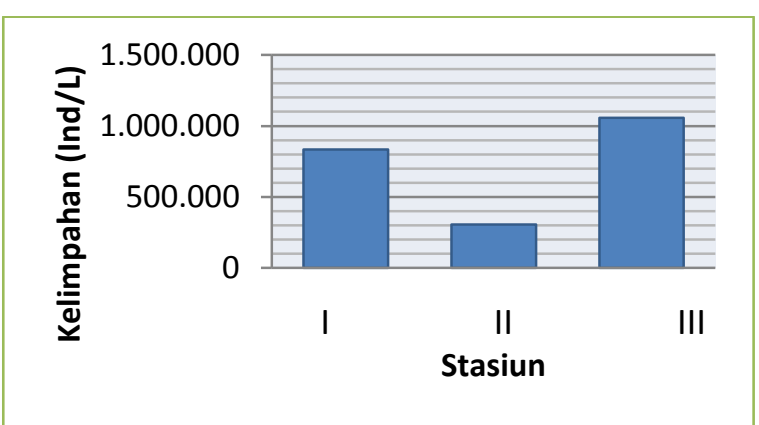

Gambar 1. Rata-rata Nilai Kelimpahan Plankton (Individu/Liter)

\section{Keanekaragaman Plankton}

Berdasarkan nilai indeks keanekaragaman, pada stasiun 1, 2, 3 berturut turut menunjukkan nilai rata-rata sebesar 0,049 ; 0,028 dan 0,040

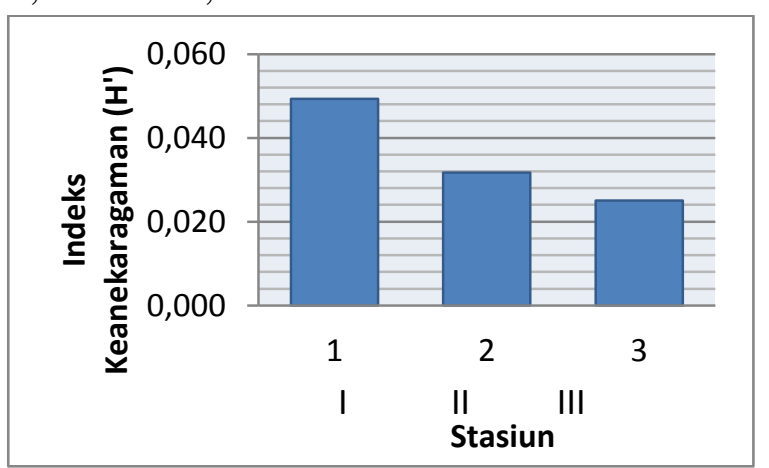

Gambar 2. Rata-rata Indeks Keanekaragaman

\section{Dominasi Plankton}

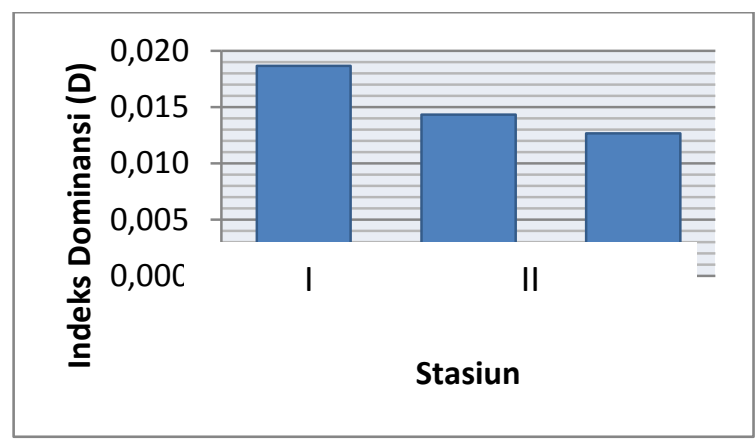

Gambar 3. Rata-rata Indeks Dominasi

Tabel 2. Nilai Kelimpahan Indeks

Keanekaragaman, dan Indeks

Dominansi Plankton

\begin{tabular}{ccccc}
\hline $\begin{array}{c}\text { Sta } \\
\text { siu } \\
n\end{array}$ & $\begin{array}{c}\text { Titik } \\
\text { Sampli } \\
\text { ng }\end{array}$ & $\begin{array}{c}\text { Kelimpaha } \\
\text { (Individu/ } \\
\text { L) }\end{array}$ & $\begin{array}{c}\text { Indeks } \\
\text { Keanekar } \\
\text { agaman } \\
\left(H^{\prime}\right)\end{array}$ & $\begin{array}{c}\text { Indeks } \\
\text { Domin } \\
\text { asi (D) }\end{array}$ \\
\hline I & IA & 2.086 .259 & 0,025 & 0,023 \\
\hline & IB & 254.34 & 0,062 & 0,017 \\
\hline & IC & 158.256 & 0,061 & 0,016 \\
\hline & Rata2 & 832.952 & 0,049 & 0,019 \\
\hline II & IIA & 418.248 & 0,044 & 0,01 \\
\hline & IIB & 196.407 & 0,025 & 0,017 \\
\hline & IIC & 299.556 & 0,026 & 0,016 \\
\hline Rata2 & 304.737 & 0,032 & 0,014 \\
\hline III & IIIA & 1.044 .207 & 0,021 & 0,013 \\
\hline & IIIB & 481.833 & 0,026 & 0,013 \\
\hline & IIIC & 1.644 .732 & 0,028 & 0,012 \\
\hline & Rata2 & 1.056 & 0,025 & 0,013 \\
\hline
\end{tabular}

Pada Tabel 2 menunjukkan bahwa nilai ratarata kelimpahan plankton tertinggi pada stasiun 3 yaitu 1.056.924 Ind/L dari semua stasiun. Dari hasil perhitungan nilai rata rata indeks keanekaragaman plankton, nilai tertinggi berada pada stasiun 1 yaitu $\mathbf{0 , 0 4 9}$ dan terendah pada stasiun 3 sebesar $\mathbf{0 , 0 2 5}$. Sedangkan untuk nilai indeks dominansi, nilai rata - rata tertinggi pada stasiun 1 berada pada 0,019 dan terendah pada stasiun 3 sebesar $\mathbf{0 , 0 1 3}$ 
Indeks Saprobik Komunitas Plankton $=-0,73$. Hal ini menunjukkan bahwa Untuk Tingkat Pencemaran Perairan tingkatan pencemaran mulai dari sangat ringan (oligo/ $\beta$-mesosaprobik) hingga agak

Tabel 3. Jenis Plankton di 3 Stasiun tinggi $\alpha$-mesosaprobik.

Pengamatan

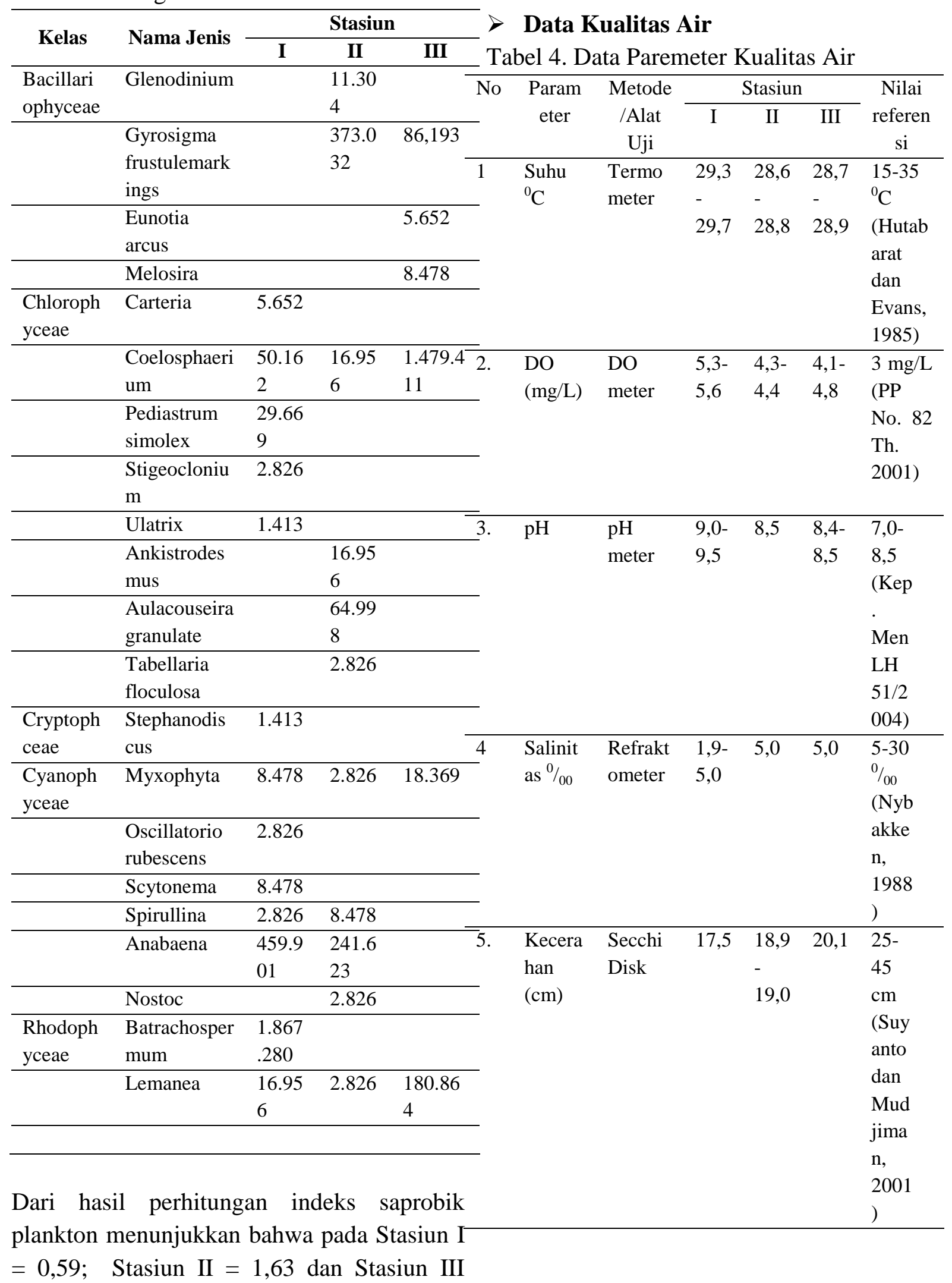




\section{PEMBAHASAN}

\section{Kelimpahan Plankton}

Kelimpahan plankton yang paling banyak ditemukan di tambak polikultur adalah Batrachospermum di stasiun 1 yang lokasinya di mulut Tambak Polikultur dengan kelimpahan rata-rata 622.427 individu/L. Murdjani dan Darmawan (2005) menjelaskan bahwa perairan dengan kelimpahan >12.000 Ind/L adalah tingkat tinggi (Eutrooph). Di stasiun 2, memiliki nilai kelimpahan rata-rata sebesar 17.926 individu/L dan jenis yang paling dominan adalah Gyrosigma, dari kelas bacilariophyceae. Sachlan (1986) menyatakan bahwa fitoplankton dari kelas Bacillariophyceae bersifat kosmopolit dan cepat berkembang. Berdasarkan rata-rata kelimpahan planktonnya, perairan tambak tergolong perairan yang eutrooph (tingkat tinggi), dengan kelimpahan >12.000 Ind/L. Stasiun 3, nilai kelimpahan rata-rata sebesar 81.302 individu/L dan dan yang paling berlimpah adalah spesies Coelosphaerium, dari kelas Cyanophyceae (alga hujau biru), sehingga warna air tambak polikultur berwarna hijau pekat. Sachlan (1986) menyatakan bahwa fitoplankton dari kelas Cyanophyceae cenderung sangat mudah mengalami perbanyakan (blooming), dan sangat toleran terhadap berbagai kondisi kualitas air. Berdasarkan rata-rata kelimpahan planktonnya, perairan tambak tergolong perairan yang eutrooph (tingkat tinggi), dengan kelimpahan >12.000 Ind/L. Dari hasil analisis kelimpahan plankton yang ada perairan tambak polikultur Desa Pelangwot, Kecamatan Laren masuk ke dalam eutropik, Landner (1974) dalam Kholik (1997) menyebutkan bahwa perairan eutropik adalah perairan yang memiliki kelimpahan fitoplakton lebih dari 15.000 ind/L.

\section{Keanekaragaman Plankton dan Dominasi Plankton}

Secara keseluruhan, indeks keanekaragaman rata-rata berada dalam kisaran 0,025-0,049. Dan untuk indeks dominansi berada pada kisaran 0,0130,019. Apabila dilihat dari nilai indeks keanekaragamannya, maka stasiun 1, 2, dan 3 menunjukkan keanekaragaman kecil dan kestabilan rendah, ini dikarenakan nilainya lebih kecil dari 2,3026. Sedangkan untuk nilai indeks dominansi di seluruh stasiun berada pada kisaran 0,013-0,019. Nilai indeks dominansi mendekati angka 0 , sehingga dapat disimpulkan bahwa tidak ada spesies yang mendominasi di seluruh stasiun.

\section{> Parameter Kualitas Air}

Berdasarkan hasil pengukuran in situ didapatkan bahwa perairan di tambak polikultur mempunyai nilai suhu yang ideal yaitu berkisar antara $28,6-29,7{ }^{\circ} \mathrm{C}$. Menurut APA (1989) bahwa suhu optimum untuk pertumbuhan fitoplankton berkisar antara 20-30 ${ }^{\circ}$ C. Salah satu faktor yang sangat penting dalam mengatur proses kehidupan dan penyebaran organisme adalah temperatur (Nybakken, 1988). . Menurut Supriharjono (2000) Pertumbuhan yang optimal Phylum Chlorophyta akan terjadi pada kisaran temperatur $30{ }^{\circ} \mathrm{C}-35{ }^{\circ} \mathrm{C}$ dan untuk diatom pada temperatur $20{ }^{0} \mathrm{C}-30$ ${ }^{0} \mathrm{C}$.

Nilai derajat keasaman $(\mathrm{pH})$ perairan sebesar 8,4 -9,5. pH diperairan tambak polikultur tersebut berada diatas kisaran baku mutu air Kep.Men LH 51/2004, yaitu 7-8,5. Pada stasiun 1, dengan nilai kecerahan sebesar $17,5 \mathrm{~cm}$, maka mengakibatkan nilai $\mathrm{pH}$ cenderung tinggi, sehingga kemungkinan dapat menyebabkan pertumbuhan lambat (Suyanto dan Mudjiman, 2001). 
Nilai salinitas di semua stasiun menunjukkan angka sebesar 1,9-5,0 \%o, untuk salinitas di perairan tawar dapat dikatakan pada kondisi baik. Hutabarat dan Evans (1985) menyatakan bahwa salinitas mempengaruhi penyebaran plankton, benthos dan organisme perairan yang lainnya.

Berdasarkan data lapang di semua stasiun diperoleh kandungan oksigen terlarutnya berkisar 4,1-5,6 mg/L artinya berada di atas kriteria mutu air yang diperbolehkan sebesar $>3 \mathrm{mg} / \mathrm{L}$ (PP No.82 tahun 2001).) Oksigen terlarut (DO) dalam air dipengaruhi oleh faktor suhu dan kadar garam, jika kelarutan oksigen dalam air menurun, maka suhu dan kadar garam meningkat.

\section{Uji T}

Berdasarkan hasil perhitungan dengan menggunakan software SPSS 17 dari semua stasiun diperoleh kesimpulan yaitu Uji T dengan pengujian sampel perpasangan (paired sample $\mathrm{T}$ Test) menunjukkan kelimpahan Plankton Stasiun A terhadap B Stasiun, Stasiun A terhadap Stasiun C, dan Stasiun B terhadap Stasiun C, hasilnya berada pada $\mathrm{t}$ hitung $<\mathrm{t}$ tabel, Pada $\propto 0.05$ : tolak Ha, terima Ho, berarti tidak ada pengaruh yang signifikan antara masingmasing stasiun. Maka dapat dinyatakan bahwa "tidak ada kesesuaian kualitas air berdasarkan kepadatan plankton" dalam tambak polikultur.

\section{Indeks Saprobik Plankton}

Nilai indeks saprobik di tambak polikultur menunjukkan bahwa perairan tersebut tergolong tercemar sangat ringan hingga agak tinggi ( $\alpha$ - Mesosaprobik), yaitu antara -0,73 sampai 1,63 (Dresscher \& Mark, 1976, Belingger \& Sigee, 2010 dalam
Sagala, 2010). Untuk kategori sangat ringan terjadi di stasiun II (Tambak dekat dengan sumber air), sedangkan kategori agak tinggi terjadi pada stasiun III (Tambak yang jauh pemukiman dan sumber air). Pada stasiun III, selaras dengan adanya aktivitas pertambakan yang menyebabkan ledakan alga serta menurunnya kualitas air. Nutrisi dalam bentuk pupuk dapat memasuki perairan dan mengalami proses dekomposisi oleh mikroorganisme perairan menjadi senyawa anorganik yang dapat memacu perkembangan organisme fotoautotrof (Pitoyo \& Wiryanto, 2002). Selain itu, perubahan musim dan faktor kimia-fisika dapat mempengaruhi nilai indeks saprobik yang dikarenakan berubahnya struktur komunitas fitoplankton (Rakocevic-Nedovic \& Hollert, 2005).

\section{KESIMPULAN}

Dari hasil penelitian, Evaluasi Tingkat Kelayakan Kualitas Air dan Pencemaran Pada Tambak Polikultur Berdasarkan Kepadatan Plankton di Desa Pelangwot Kecamatan Laren Kabupaten Lamongan Propinsi Jawa Timur, maka dapat disimpulkan sebagai berikut :

1. Berdasarkan nilai kelimpahan pada stasiun 1, 2, dan 3 maka perairan di tambak polikultur pada kategori eutropik, karena $>15.000$ Ind/L. Nilai indeks keanekaragaman berada pada kisaran 0.125-0,049 artinya menunjukkan keanekaragaman kecil dan kestabilan rendah. Dan untuk rata-rata nilai indek dominansi berkisar 0,013-0,019, mendekati angka 0 , sehingga dapat disimpulkan tidak ada plankton yang mendominasi perairan,

2. Pada pengukuran parameter kualitas air di semua stasiun, menunjukkan hasil suhu berada pada kisaran 28,6-29,7 ${ }^{0} \mathrm{C}$; DO (Oksigen terlarut) pada nilai kisaran 4,1- 
5,6 mg/L; pH berkisar 8,4-9,5 dalam kondisi tinggi, yang dapat berdampak pada pertumbuhan ikan. Salinitas berada pada kisaran 1,9-5,0 yang berarti sesuai dengan kehidupan organisme/kultivan untuk perairan tawar dan kecerahan cenderung pekat berkisar 17,5-20 $\mathrm{cm}$ disebabkan oleh pertumbuhan plankton yang cukup pekat.

3. Nilai indeks saprobik di tambak polikultur menunjukkan bahwa perairan tersebut tergolong tercemar sangat ringan hingga agak tinggi ( $\alpha$ - Mesosaprobik), yaitu antara -0,73 sampai 1,63.

\section{DAFTAR PUSTAKA}

APA. 1989. Standard Methods for the Examination of Water and Wastewater. 17th edition. Washington D.C. 3464 pp.

Dinas Perikanan dan Kelautan Kabupaten Lamongan. 2014. Data Potensi Perikanan Budidaya Kabupaten Lamongan. Laporan Tahunan 2014

Fachrul, Melati F., Herman H., dan Listari C. Sitepu. 2005. Komunitas fitoplankton sebagai bioindikator kualitas perairan teluk Jakarta. Dalam : Seminar Nasional MIPA. FMIPA Universitas Indonesia. Depok, 24-26 november 2005.

Keputusan Menteri Lingkungan hidup No. 51

Tahun 2004 tentang Baku Mutu Air Laut. Jakarta

Kholik, 1997. Struktur Komunitas

Fitoplankton Pada Daerah yang

Terbuka dan Tertutup Oleh Gulma Air

di danau Taliwang Kabupaten

Sumbawa, Nusa Tenggara

Barat. Skripsi. Fakultas Perikanan, IPB.

Nybakken, J. W. 1988. Biologi Laut, Suatu Pendekatan Ekologis. Terjemahan:
Koesoebiono, D. G. Bengen, M, Eidman. Marine Biology, An Ecology Approach, PT. Gramedia, Jakarta.

Odum, E.P.1971. Fundamentals of Ecology.

Third Edition. W.B. Sounders

Company. Philadelphia,London,

Toronto. Toppan Company, Ltd.

Tokyo, Japan.574 p.

Peraturan Pemerintah Republik Indonesia

Nomor 82 Tahun 2001 Tentang

Pengelolaan Kualitas Air dan

Pengendalian Pencemaran Air.

Sekretaris Negara Republik Indonesia.

Romimohtarto,K dan S.Juwana. 2005.

Biologi Laut : Ilmu Pengetahuan tentang Biologi Laut. Cet. ke-2. Penerbit Djambatan,Jakarta.540 hlm.

Sachlan, M. 1982. Planktonologi. Fakultas

Peternakan. Universitas Diponegoro,

Semarang.

Sagala, Effendi Parlindungan. 2010. Indeks Saprobik Komunitas dalam Menentukan Tingkat Pencemaran di Perairan Laut antara Muara Sungai Benu dan Pulau Betet, Kabupaten Banyuasin, Propinsi Sumatera Selatan. Jurusan Biologi Fakultas MIPA Universitas Sriwijaya

Syahid, M., Subhan, A., \& Armando, R. 2006. Budidaya Udang Organik secara Polikultur. Penebar Swadaya. Jakarta, $75 \mathrm{hlm}$

Suyoto, 2013. Kajian Kualitas Air dimuara Kawasan Mangrove Desa Sedayu Lawas Kecamatan Brondong Lamongan ditijau dari indeks keanekaragaman dan indeks saproditas plankton [skripsi] Program Studi Managemen Sumber Daya Perairan Unisla

Yazwar. 2008. Keanekaragaman Plankton dan Keterkaitannya dengan Kualits air di Parapat Danau Toba. Tesis. Sekolah Pascasarjana. USU. Medan. 